\title{
Care plan use among older people with functional impairment: analysis of the English General Practice Patient Survey
}

\author{
Alice Shiner BSc (Hons) MBChB (Hons) MClinEd FRCGP ${ }^{a}$, John A. Ford MSc MFPH ${ }^{b}$ and \\ Nicholas Steel PhD FFPH \\ a CLAHRC GP Research Fellow \& Honorary Senior Lecturer, Department of Population Health and Primary Care, Norwich \\ Medical School, Faculty of Medicine and Health Sciences, University of East Anglia, Norwich, UK \\ b NIHR Doctoral Research Fellow, Department of Population Health and Primary Care, Norwich Medical School, \\ University of East Anglia, Norwich, UK \\ c Clinical Professor in Public Health, Department of Population Health and Primary Care, Norwich Medical School, \\ University of East Anglia, Norwich, UK
}

\begin{abstract}
Objectives: Care plans may improve health when patients are involved in the care planning process. They are recommended for primary care. This study aimed to identify characteristics of older patients with functional impairment (age $\geq 75$ years with problems completing daily activities) who report having a care plan and who are involved in care planning.

Methods: The General Practice Patient Survey (individual-level dataset) 2015-16 in England was analysed. Logistic regression was used to estimate associations between having a care plan and being involved with care planning and age, gender, ethnicity, deprivation, multimorbidity, interpersonal relationship with general practitioner (GP) and other variables, clustered at practice level.

Results: Three point five percent of GPPS respondents and $14.4 \%$ of older people with functional impairment reported having a care plan; however, only a quarter of the latter were involved with the care planning process. Involvement with care planning was associated with seeing own GP (odds ratio (OR) 1.88, 95\% confidence interval (CI) 1.48 to 2.38 ) and factors reflecting a positive interpersonal relationship with the GP, including having confidence in the GP (OR 5.92, CI 2.38 to 14.77). Respondents involved with care planning reported greater confidence in managing their own health.

Conclusions: Few older people with functional impairment report having a care plan and fewer report involvement in the care planning process. This may reduce the ability of care plans to deliver health benefits and person-centered care.
\end{abstract}

\section{Keywords}

Care plans, collaborative goal setting, frailty, functional impairment, long term conditions, multimorbidity, patient activation, patient engagement, person-centered healthcare, self-efficacy, self-management, shared decision-making, social care

\section{Correspondence address}

Dr. Alice Shiner, CLAHRC GP Research Fellow, Department of Population Health and Primary Care, Norwich Medical School, Faculty of Medicine and Health Sciences, University of East Anglia, Norwich, NR4 7TJ, UK.

E-mail: A.Shiner@uea.ac.uk

Accepted for publication: 23 March 2018

\section{Introduction}

Care planning is a clinical tool designed to improve patient care. It should involve a conversation between an individual and a healthcare professional, with shared decision-making and agreed goals set to manage the patient's conditions [1,2]. Although the evidence is mixed [3], care plans can improve some indicators of physical and psychological health in long-term conditions [1] and enhance self-management [4].

No studies have found that care plans improve outcomes among patients with multimoribidity, yet the holistic approach involved is well suited to this patient group, particularly those who are older and with functional impairment (i.e., most frail patients) [5]. They are recommended in clinical guidelines for single diseases as well as multimorbidity [6] and have been a recurring theme in UK health policy for at least a decade [7]. From 20142017 GPs in England were given financial incentives to offer them as part of the 'Avoiding Unplanned Admissions' (AUA) Enhanced Service [8]. Globally, most countries have a growing older population with many individuals living with multiple chronic diseases [9] and care planning has been adopted for management of chronic 
disease by many primary healthcare systems worldwide [10].

The GP Patient Survey (GPPS) is an independent survey run by Ipsos MORI on behalf of NHS England that collects data about patient experiences of primary care. Since 2013 it has included four questions about 'planning your care' [11]. Previous analyses of GPPS data have found that few patients report having a written care plan $[12,13]$. However, these studies did not focus on older people and, with an increasingly ageing population, this may be an important omission. Also, as it is known that the effects of care planning are greater when more stages of the care planning cycle are completed [1], the level of involvement in care planning warrants exploration.

This study analyses individual-level, 2015-16 GPPS data. We set out to determine how many older functionally impaired people report having a care plan and, of those, what proportion report involvement in the care planning process. We studied the factors associated with this population having a care plan and being involved with care planning.

\section{Method}

\section{GPPS sample}

Patients were sampled using registration records held by the Health and Social Care Information Centre. The inclusion criteria were: a valid NHS number, being registered with the general practice continuously for $>6$ months and $\geq 18$ years. An unclustered, proportionally stratified (by age and sex) sample that took account of practice size and previous response rate was drawn from all 7778 practices in England. Around 2.15 million surveys were posted out across 2 GPPS waves, from July 2015 to September 2015 and January 2016 to March 2016, with reminders sent if no response was received. Patients had the option of completing the survey on paper, online, or by telephone and in up to 14 different languages plus British Sign Language. Full technical details are published elsewhere [14].

\section{GPPS data}

The questionnaire contained a total of 62 questions relating to a patient's characteristics and experiences of general practice. Regarding care planning, the survey asked:

- 'Do you have a written care plan?'

- 'Did you help put your written care plan together? (by 'help' we mean setting goals for yourself or choosing how you want to manage your health)'

- 'Do you use your written care plan to help you manage your health day-to-day?'
- 'Does your GP, nurse or other health professional review your written care plan with you regularly?'

The responses were 'yes', 'no', or sometimes 'don't know'.

Additional questions asked about age, gender, ethnicity (we grouped this into white and non-white, as only $4.3 \%$ of the population were non-white), presence of a longstanding health condition, function (indicated by ability to complete usual activities and whether this is due to shortor long-term conditions), frequency of seeing a GP, confidence in managing own health, several questions relating to the experience of using GP services, and use of local services or organisations to help manage long-term health conditions. An Index of Multiple Deprivation (IMD) score (based on postcode) was available for each patient. Full text of the survey is available online [11].

\section{Statistical analysis}

Using individual-level data, we calculated the proportion of the whole sample who had a care plan. We then calculated the proportion of the whole sample who were older and had functional impairment, based on if:

1. They stated they had moderate/severe problems or were unable to do their usual activities and

2. This was not limited because of recently being unwell or injured and

3. They were $\geq 75$ years old.

A second binary variable was created for being 'involved in care planning' if a respondent stated that they:

\section{Had a care plan and}

2. Answered 'yes' to all questions about care planning (listed above).

Logistic regression was used to examine the relationship between the outcome variables of (A) having a care plan and (B) being involved with care planning and explanatory variables. Explanatory variables were chosen based on theoretical links and included: (1) frequency of consultation, (2) factors related to experience with GP, (3) confidence in GP, (4) seeing GP of preference, (5) overall experience and recommendation to others, (6) presence of a long-standing health condition, (7) multimorbidity, (8) support received from local services and (9) confidence in managing own health (see Tables 3 for details of variables). Adjustment was made for: (i) age (75-84 years, $85+$ years); (ii) gender; (iii) ethnicity and (iv) IMD score. To account for patient groups potentially clustering in practices that may perform generally better or worse, regression analyses were clustered at practice level. Analyses were undertaken in Stata (Version 13) [15]. 


\section{Ethical approval}

Ethical approval was obtained from the Yorkshire \& Humber - Bradford Leeds Research Ethics Committee. (REC Ref. 16/YH/0437).

\section{Results}

A total of 2,148,791 questionnaires were mailed for the 2015-16 GPPS, of which 836,312 were returned, giving a response rate of $38.9 \%$ [13]. Among all respondents, 3.5\% $(n=28,983)$ reported that they had a written care plan. The proportion of respondents identified as older with functional impairment was $2.8 \%(n=23,508)$ (Table 1). Of these, $14.4 \%(n=3,377)$ reported having a care plan and of these $25 \%(n=844)$ were involved with the care planning process (Table 2). Key characteristics of older people with functional impairment included being white (94.7\%), female $(58.1 \%)$ and having a long-standing health condition (89.3\%) (Table 3).

\section{Care plans in older people with functional impairment}

People in this group who were aged $\geq 85$ years were more likely than those who were $75-84$ years to report having a care plan (adjusted OR 2.11, 95\% CI 1.96-2.27), as were women $(1.14,1.05-1.23)$ and those living in more deprived postcode areas $(1.16,1.05-1.23)$ (Table 4). Being seen within the last 6 months $(1.43,1.28-1.61)$ and the presence of a long-standing health condition $(2.58,2.06-3.25)$ also made reporting a care plan more likely. Those who reported a care plan were less likely to feel confident in managing their own health $(0.53,0.5-0.56)$ and less likely to report receiving enough support from local services $(0.88,0.87-0.9)$. There was little difference between crude and adjusted OR, so for clarity only adjusted OR are presented.

\section{Involvement with care planning}

The variables most associated with involvement in care planning related to the respondent reporting positive interpersonal experiences with their GP, particularly having confidence in the GP $(5.92,2.38-14.77)$, as well as the ability to see a preferred GP $(1.88,1.48-2.38)$, having a positive overall experience $(1.51,1.33-1.72)$ and willingness to recommend the practice to others $(1.43$, 1.29-1.59). Unlike the relationship seen for having a care plan, being involved with care planning was associated with increased confidence in managing own health $(1.31$, 1.2-1.42). Being involved with care planning was also associated with the reporting of insufficient support from local services $(0.85,0.8-0.9)$ (Table 4$)$.

Table 1 Characteristics of GPPS respondents $(2015-16)(n=836,312)$

\begin{tabular}{|c|c|c|}
\hline Variable & Number & Percentage \\
\hline \multicolumn{3}{|l|}{ Age } \\
\hline Over 75 years & 130,041 & $15.5 \%$ \\
\hline Under 75 years & 691,894 & $82.7 \%$ \\
\hline Not answered & 14,377 & $1.7 \%$ \\
\hline \multicolumn{3}{|l|}{ Function } \\
\hline Long-term significantly reduced ability to perform usual activities & 67,334 & $8.1 \%$ \\
\hline $\begin{array}{l}\text { No/very minimal reduction in ability to perform usual activities, or reduction related to short term } \\
\text { illness }\end{array}$ & 726,306 & $86.8 \%$ \\
\hline Not answered & 42,672 & $5.1 \%$ \\
\hline \multicolumn{3}{|l|}{ Older people with functional impairment } \\
\hline Over 75 years and with functional impairment & 23,508 & $2.8 \%$ \\
\hline Under 75 years or no functional impairment & 759,027 & $90.8 \%$ \\
\hline Not answered & 53,777 & $6.4 \%$ \\
\hline \multicolumn{3}{|l|}{ Care plan } \\
\hline Yes & 28,983 & $3.5 \%$ \\
\hline No & 747,720 & $89.4 \%$ \\
\hline Not answered & 60,059 & $7.2 \%$ \\
\hline
\end{tabular}


Table 2 Care plan responses of older population with functional impairment in the GPPS $2015-16$ $(n=23,508)$

\begin{tabular}{|c|c|c|}
\hline Variable & Number & Percentage \\
\hline $\begin{array}{l}\text { Have a written care plan }(n=23,508) \\
\text { Yes } \\
\text { No } \\
\text { Not answered }\end{array}$ & $\begin{array}{c}3,377 \\
18,148 \\
1,983\end{array}$ & $\begin{array}{c}14.4 \% \\
77.2 \% \\
8.4 \%\end{array}$ \\
\hline $\begin{array}{l}\text { Helped to put care plan together }(n=3,377) \\
\text { Yes } \\
\text { No } \\
\text { Not answered }\end{array}$ & $\begin{array}{c}1,984 \\
1,200 \\
193\end{array}$ & $\begin{array}{c}58.8 \% \\
35.5 \% \\
5.7 \%\end{array}$ \\
\hline $\begin{array}{l}\text { Use care plan to help manage health day-to-day }(n=3,377) \\
\text { Yes } \\
\text { No } \\
\text { Not answered }\end{array}$ & $\begin{array}{c}1,831 \\
1,321 \\
225\end{array}$ & $\begin{array}{c}54.2 \% \\
39.1 \% \\
6.7 \%\end{array}$ \\
\hline $\begin{array}{l}\text { Care plan regularly reviewed with a healthcare professional }(n=3,377) \\
\text { Yes } \\
\text { No } \\
\text { Not answered }\end{array}$ & $\begin{array}{c}1,731 \\
899 \\
747\end{array}$ & $\begin{array}{l}51.3 \% \\
26.6 \% \\
22.1 \%\end{array}$ \\
\hline $\begin{array}{l}\text { Involved with all aspects of care planning }(n=3,377) \\
\text { Yes } \\
\text { No } \\
\text { Not answered }\end{array}$ & $\begin{array}{c}844 \\
2,122 \\
411\end{array}$ & $\begin{array}{c}25 \% \\
62.8 \% \\
12.2 \%\end{array}$ \\
\hline
\end{tabular}

Table 3 Key characteristics of older population with functional impairment in the GPPS 2015-16*

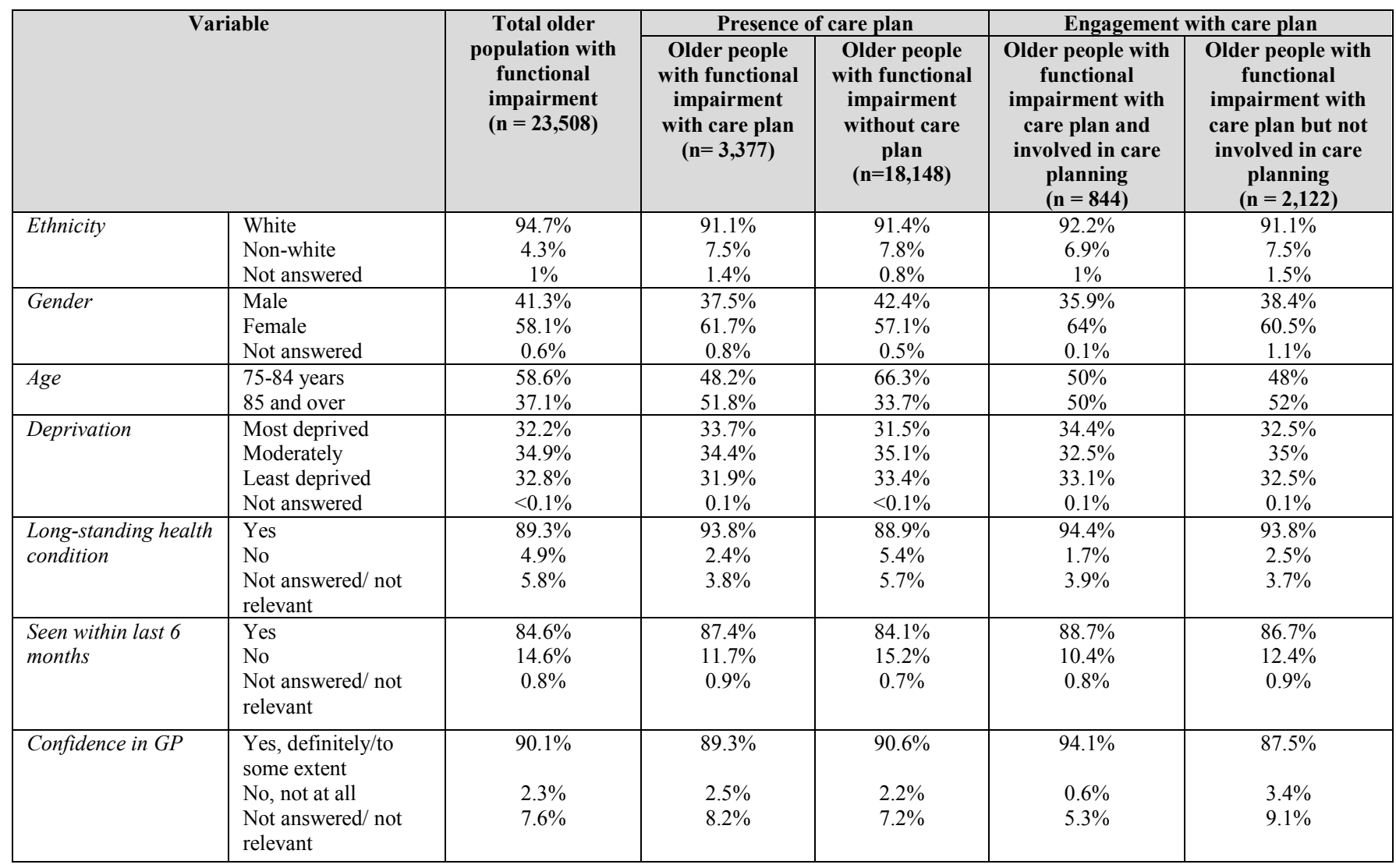




\begin{tabular}{|c|c|c|c|c|c|c|}
\hline $\begin{array}{l}\text { Seeing GP of } \\
\text { preference }\end{array}$ & $\begin{array}{l}\text { Always/almost } \\
\text { always/a lot of the } \\
\text { time } \\
\text { Some of the } \\
\text { time/almost } \\
\text { never/never } \\
\text { Not answered/ not } \\
\text { relevant }\end{array}$ & $\begin{array}{l}5.7 \% \\
18.9 \% \\
35.4 \%\end{array}$ & $\begin{array}{l}42.5 \% \\
18.7 \% \\
38.9 \%\end{array}$ & $\begin{array}{c}46.7 \% \\
19 \% \\
34.4 \%\end{array}$ & $\begin{array}{l}50.5 \% \\
13.5 \% \\
36 \%\end{array}$ & $\begin{array}{r}40.6 \% \\
20.8 \% \\
38.6 \%\end{array}$ \\
\hline $\begin{array}{l}\text { Overall experience } \\
\text { of GP surgery }\end{array}$ & $\begin{array}{l}\text { Very good } \\
\text { Fairly good } \\
\text { Neither good nor } \\
\text { poor } \\
\text { Fairly poor } \\
\text { Very poor } \\
\text { Not answered/ not } \\
\text { relevant }\end{array}$ & $\begin{array}{c}59.3 \% \\
31.3 \% \\
5.8 \% \\
\\
1.4 \% \\
0.5 \% \\
1.7 \%\end{array}$ & $\begin{array}{c}58.7 \% \\
29.9 \% \\
5.6 \% \\
\\
1.4 \% \\
0.6 \% \\
3.9 \%\end{array}$ & $\begin{array}{l}59.8 \% \\
31.5 \% \\
5.7 \% \\
\\
1.5 \% \\
0.4 \% \\
1.1 \%\end{array}$ & $\begin{array}{c}67.3 \% \\
25.8 \% \\
3.6 \% \\
0.6 \% \\
0 \% \\
2.7 \%\end{array}$ & $\begin{array}{r}55.2 \% \\
31.5 \% \\
6.6 \% \\
\\
1.7 \% \\
0.9 \% \\
4.2 \%\end{array}$ \\
\hline $\begin{array}{l}\text { Would recommend } \\
\text { GP surgery to others }\end{array}$ & $\begin{array}{l}\text { Yes, definitely } \\
\text { Yes, probably } \\
\text { Not sure } \\
\text { No, probably not } \\
\text { No, definitely not } \\
\text { Not answered/ not } \\
\text { relevant }\end{array}$ & $\begin{array}{c}57.4 \% \\
24.1 \% \\
9.7 \% \\
3.9 \% \\
1.6 \% \\
\\
3.3 \%\end{array}$ & $\begin{array}{c}58.4 \% \\
22.7 \% \\
8.5 \% \\
3 \% \\
2 \% \\
5.5 \%\end{array}$ & $\begin{array}{c}57.5 \% \\
24.4 \% \\
10 \% \\
4 \% \\
1.5 \% \\
\\
2.6 \%\end{array}$ & $\begin{array}{c}67.2 \% \\
20.4 \% \\
6 \% \\
1.4 \% \\
0.6 \% \\
\\
4.4 \%\end{array}$ & $\begin{array}{c}55 \% \\
23.8 \% \\
9.2 \% \\
3.7 \% \\
2.6 \% \\
\\
5.7 \%\end{array}$ \\
\hline $\begin{array}{l}\text { Enough support } \\
\text { received from local } \\
\text { services to manage } \\
\text { long-term health } \\
\text { condition/s in last } 6 \\
\text { months }\end{array}$ & $\begin{array}{l}\text { Yes, definitely/ to } \\
\text { some extent } \\
\text { No } \\
\text { Not answered/ not } \\
\text { relevant }\end{array}$ & $\begin{array}{l}62.5 \% \\
9.3 \% \\
28.2 \%\end{array}$ & $\begin{array}{l}80.2 \% \\
6.2 \% \\
13.6 \%\end{array}$ & $\begin{array}{c}59.1 \% \\
10.1 \% \\
31 \%\end{array}$ & $\begin{array}{c}87.8 \% \\
2.3 \% \\
10 \%\end{array}$ & $\begin{array}{r}77.2 \% \\
8.2 \% \\
14.7 \%\end{array}$ \\
\hline $\begin{array}{l}\text { Confidence in } \\
\text { managing own } \\
\text { health }\end{array}$ & $\begin{array}{l}\text { Very } \\
\text { Fairly } \\
\text { Not very } \\
\text { Not at all } \\
\text { Not answered /not } \\
\text { relevant }\end{array}$ & $\begin{array}{c}17.2 \% \\
55.7 \% \\
16.9 \% \\
8.1 \% \\
2.2 \%\end{array}$ & $\begin{array}{c}13.2 \% \\
40.7 \% \\
20.8 \% \\
22.5 \% \\
2.8 \%\end{array}$ & $\begin{array}{c}18.6 \% \\
58.9 \% \\
15.7 \% \\
4.9 \% \\
1.9 \%\end{array}$ & $\begin{array}{c}17.3 \% \\
45.3 \% \\
18.1 \% \\
17.2 \% \\
2.1 \%\end{array}$ & $\begin{array}{c}11.8 \% \\
38.9 \% \\
20.9 \% \\
25.5 \% \\
2.8 \%\end{array}$ \\
\hline
\end{tabular}

*Additional characteristics are set out in Table 5

Table 4 Association between patient characteristics and outcomes of reporting a care plan and involvement with care planning, for older population with functional impairment

\begin{tabular}{|c|c|c|c|}
\hline \multicolumn{2}{|l|}{ Variable } & \multirow{2}{*}{$\begin{array}{l}\text { Reports a care plan } \\
\left.\text { Adjusted } \mathbf{O R}^{*} \mathbf{( 9 5 \%} \mathbf{~ C I}\right) \\
1 \text { (baseline) } \\
\mathbf{2 . 1 1}(1.96 \text { to } 2.27)\end{array}$} & \multirow{2}{*}{$\begin{array}{l}\begin{array}{l}\text { Involved with care planning } \\
\text { Adjusted } \mathbf{O R}^{*}(\mathbf{9 5 \%} \mathbf{C I})\end{array} \\
1 \text { (baseline) } \\
0.91 \text { (0.77 to } 1.07)\end{array}$} \\
\hline Age & $\begin{array}{l}75-84 y \\
85 y \text { and over }\end{array}$ & & \\
\hline Gender & $\begin{array}{l}\text { Male } \\
\text { Female }\end{array}$ & $\begin{array}{l}1 \text { (baseline) } \\
\mathbf{1 . 1 4}(1.05 \text { to } 1.23)\end{array}$ & $\begin{array}{l}1 \text { (baseline) } \\
1.15(0.97 \text { to } 1.36)\end{array}$ \\
\hline Ethnicity & $\begin{array}{l}\text { Non-white } \\
\text { White }\end{array}$ & $\begin{array}{l}1 \text { (baseline) } \\
0.98(0.85 \text { to } 1.14)\end{array}$ & $\begin{array}{l}1 \text { (baseline) } \\
1.12(0.82 \text { to } 1.53)\end{array}$ \\
\hline Deprivation & $\begin{array}{l}\text { Least } \\
\text { Moderate } \\
\text { Most } \\
\end{array}$ & $\begin{array}{l}1 \text { (baseline) } \\
1.03(0.94 \text { to } 1.13) \\
\mathbf{1 . 1 6}(1.05 \text { to } 1.23)\end{array}$ & $\begin{array}{l}1 \text { (baseline) } \\
0.93(0.76 \text { to } 1.13) \\
1.05(0.86 \text { to } 1.28)\end{array}$ \\
\hline Seen within last 6 months & $\begin{array}{l}\text { No } \\
\text { Yes }\end{array}$ & $\begin{array}{l}1 \text { (baseline) } \\
\mathbf{1 . 4 3}(1.28 \text { to } 1.61)\end{array}$ & $\begin{array}{l}1 \text { (baseline) } \\
1.24 \text { (0.95 to } 1.6)\end{array}$ \\
\hline $\begin{array}{l}\text { Experience with GP } \\
\text { Increasing rating of: } \\
\text { Enough time** } \\
\text { Listened to** } \\
\text { Explained test/care** } \\
\text { Involved in decisions** } \\
\text { Treated with care** }\end{array}$ & & $\begin{array}{l}1.05(0.99 \text { to } 1.11) \\
1.05(0.99 \text { to } 1.11) \\
\mathbf{1 . 0 7}(1.01 \text { to } 1.13) \\
\mathbf{1 . 0 9}(1.03 \text { to } 1.15) \\
\mathbf{1 . 1 4}(1.08 \text { to } 1.2)\end{array}$ & $\begin{array}{l}\mathbf{1 . 3 8}(1.21 \text { to } 1.57) \\
\mathbf{1 . 5 5}(1.35 \text { to } 1.78) \\
\mathbf{1 . 5 4}(1.35 \text { to } 1.76) \\
\mathbf{1 . 6 2}(1.43 \text { to } 1.83) \\
\mathbf{1 . 6 2}(1.41 \text { to } 1.87)\end{array}$ \\
\hline Confidence in GP & $\begin{array}{l}\text { No, not at all } \\
\text { Yes, definitely/ to some } \\
\text { extent }\end{array}$ & $\begin{array}{l}1 \text { (baseline) } \\
0.94(0.74 \text { to } 1.2)\end{array}$ & $\begin{array}{l}1 \text { (baseline) } \\
\mathbf{5 . 9 2}(2.38 \text { to } 14.77)\end{array}$ \\
\hline Usually sees preferred GP & $\begin{array}{l}\text { Some of the time/almost } \\
\text { never/never } \\
\text { Always/almost always/a } \\
\text { lot of the time }\end{array}$ & $\begin{array}{l}1 \text { (baseline) } \\
0.95(0.85 \text { to } 1.05)\end{array}$ & $\begin{array}{l}1 \text { (baseline) } \\
\mathbf{1 . 8 8}(1.48 \text { to } 2.38)\end{array}$ \\
\hline \multicolumn{2}{|c|}{ Increasing rating of overall experience** } & $1.02(0.97$ to 1.08$)$ & $\mathbf{1 . 5 1}(1.33$ to 1.72$)$ \\
\hline \multicolumn{2}{|c|}{ Increasing rating of recommendation to others** } & $\mathbf{1 . 0 6}(1.01$ to 1.1$)$ & $\mathbf{1 . 4 3}(1.29$ to 1.59$)$ \\
\hline \multicolumn{2}{|c|}{ Multimorbidity (increasing numbers of conditions) } & $\mathbf{1 . 1 1}(1.08$ to 1.14$)$ & $1.00(0.95$ to 1.05$)$ \\
\hline $\begin{array}{l}\text { Presence of a long-standing health } \\
\text { condition }\end{array}$ & $\begin{array}{l}\text { No } \\
\text { Yes }\end{array}$ & $\begin{array}{l}1 \text { (baseline) } \\
\mathbf{2 . 5 8}(2.06 \text { to } 3.25)\end{array}$ & $\begin{array}{l}1 \text { (baseline) } \\
1.45 \text { (0.8 to } 2.63)\end{array}$ \\
\hline Enough support received from loca & No & 1 (baseline) & 1 (baseline) \\
\hline
\end{tabular}




\begin{tabular}{|l|l|l|l|}
\hline $\begin{array}{l}\text { services to manage long-term health } \\
\text { condition/s in last } 6 \text { months }\end{array}$ & Yes & $\mathbf{0 . 8 8}(0.87$ to 0.9$)$ & $\mathbf{0 . 8 5}(0.8$ to 0.9$)$ \\
\hline \multicolumn{2}{|l|}{ Increasing confidence in managing own health** } & $\mathbf{0 . 5 3}(0.5$ to 0.56$)$ & $\mathbf{1 . 3 1}(1.20$ to 1.42$)$ \\
\hline
\end{tabular}

* Adjusted for age, gender, ethnicity and deprivation. ${ }^{* *}$ see table 3 for scales $\mathrm{OR}=$ odds ratio, $\mathrm{CI}=$ confidence interval

Table 5 Additional characteristics of frail older population in the GPPS 2015-16

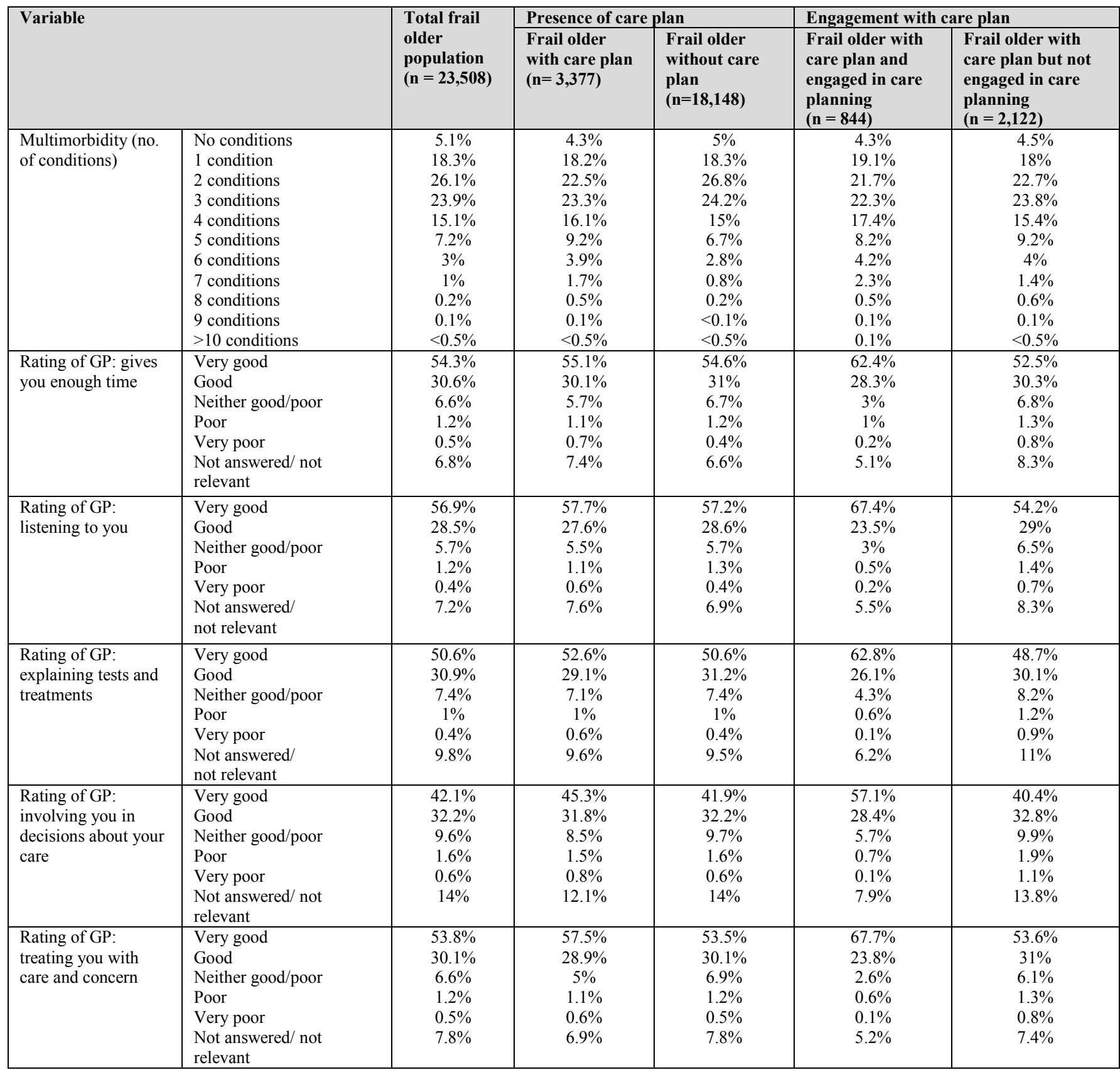

\section{Discussion}

Many frailty measures are based on disability and comorbidity [16] and our sample is likely to have considerable overlap with those who are frail. We have shown that $14.4 \%$ of older patients with functional impairment report having a care plan, but this figure is low considering that this is likely to be a frail population who may have been eligible for care plans during the 2014-17 Enhanced Service [8]. Reports of previous analyses of
GPPS data have also found that care plans are reported by patients less often than expected $[12,13]$. One of these studies found that care planning discussions took place more often than patients reported having a written care plan [12]; respondents in our study may have also had care planning discussions without having a written plan.

Little has been published regarding the extent to which frail older people are involved in care planning. A recent systematic review of collaborative goal setting with older patients with chronic disease found only eight relevant articles on the subject and reported nothing about the level of participant involvement in interventions [17]. However, 
patient activation (including self-efficacy) has parallels with involvement and a large prospective cohort study found that older people in the UK vary in their levels of activation, with lower levels among depressed, older, retired people with poor health literacy and those who lack social support [18]. Patients who are more 'activated' are more likely to engage in self-management, have a higher quality of life, better clinical outcomes and make informed decisions about accessing health or social care resources [19].

Some of the factors that can facilitate engagement have been identified. A systematic review found that continuity of care was key to developing the doctor-patient relationship needed to facilitate patient engagement [20] and that poor continuity leads to care planning that is often inconsistent and incomplete [21]. A Cochrane review found that the effects of care planning were greater when there were more contacts between patients and health professionals and when the patient's usual clinician was involved [1]. Additional facets of interpersonal care from the GP also matter: previous GPPS data analysis also found that strong predictors of care planning activities were continuity of care and high ratings of interpersonal care from the GP [13].

The strengths of the present study include the large sample of over 836,000 responders, with 23,508 older functionally impaired respondents. The questionnaire was available online, by telephone, or on paper in 14 different languages, thereby facilitating an increased response rate. Limitations include the potential for participation bias, due to non-inclusion of patients without a GP or who had recently moved GP practice, risking under-representation of individuals without a permanent home or with disorganised lives (this may include vulnerable older people). We do not have data comparing respondents versus non-respondents, but frail people (who may have been more likely to have had a care plan) may have been unable to complete the survey. We also lack detail about the care plans, for example what conditions they were issued for. Additionally, our results are based on selfreported perceptions thus patients may have had care plans but not been aware of them (although as a care plan is more effective if a person is aware of it thus using selfreporting may be appropriate). Finally, our study can report association, but not causation. If causal relationships were present these could operate in both directions, for example, being involved in care planning may make people more confident in managing their own health, or those who are more confident may be more likely to become involved in care planning.

The relatively infrequent reporting of care plans among older people, particularly at a time during which care plans were being offered to this group as part of an Enhanced Service, suggests that either care plans are not offered enough to this population or patients are unaware of their existence (in which case they lose the potential to offer health benefits). Those who were involved in the care planning process rated their GP more highly for interpersonal care.

\section{Conclusion}

We found that few GPPS respondents (3.5\%) reported having a care plan. Of the older people with functional impairment, $14.4 \%$ reported having a care plan and of these only 1 in 4 were involved with the care planning process. Involvement with care planning was associated with greater confidence in managing own health and factors reflecting a positive interpersonal relationship with the GP.

Future research is required to help understand the extent to which frail older patients benefit from care plans. As care plans function better when patients are involved in the process [1], future studies should explore the factors that enhance involvement. It is important to understand if the care plan can act as a mechanism of involvement, which may reduce health service use, or if those who are involved in care planning are confident in managing their own health and hence may already utilise less healthcare resources. Finally, components of care planning such as shared decision-making and goal-setting require further exploration.

This study has shown that only a small number of older adults with functional impairment have care plans and even fewer are involved in the care planning process. If care plans are to achieve their potential in increasing the person-centeredness of care then GPs need sufficient time and resources to establish good interpersonal relationships with patients and mechanisms are needed to ensure continuity of care.

\section{Acknowledgements and Conflicts of Interest}

This is a summary of independent research funded / supported by the National Institute for Health Research Collaboration for Leadership in Applied Health Research and Care East of England Programme. The views expressed are those of the author(s) and not necessarily those of the NHS, the NIHR or the Department of Health and Social Care. The authors declare no conflicts of interest.

\section{References}

[1] Coulter, A., Entwistle, V.A., Eccles, A., Ryan, S., Shepperd, S. \& Perera, R. (2015). Personalised care planning for adults with chronic or long-term health conditions. Cochrane Database of Systematic Reviews (3): CD010523.

[2] Lhussier, M., Eaton, S., Forster, N., Thomas, M., Roberts, S. \& Carr, S.M. (2015). Care planning for longterm conditions - a concept mapping. Health Expectations 18 (5) 605-624.

[3] Bower, P., Reeves, D., Roland, M. et al. (2013). Care planning in the treatment of long-term conditions: final report of the CAPITOL project. Available at: 
http://hrep.lshtm.ac.uk/publications/Care\%20planning_fina 1_Bower\%20et\%20al_7\%20Mar\%2013.pdf (accessed 18 Dec 2017).

[4] Lenzen, S.A., Daniëls, R., van Bokhoven, M.A., van der Weijden, T. \& Beurskens, A. (2015). Setting goals in chronic care: Shared decision making as self-management support by the family physician. European Journal of General Practice 21 (2) 138-144.

[5] Boyd, C. \& Fortin, M. (2013). Future of Multimorbidity Research: How should Understanding of Multimorbidity Inform Health System Design? Public Health Reviews 32 (2) 451-474.

[6] National Institute for Health and Care Excellence. (2016). NG56 Multimorbidity: clinical assessment and management. London: NICE.

[7] NHS England. (2015). Personalised care and support planning handbook: the journey to person-centred care. Available at: https://www.england.nhs.uk/wpcontent/uploads/2016/04/core-info-care-support-planning1.pdf (accessed 7 March 2018).

[8] NHS England. (2015). Enhanced service specification. Avoiding unplanned admissions: proactive case finding and patient review for vulnerable people 2015/16. Available at:

https://www.england.nhs.uk/commissioning/wpcontent/uploads/sites/12/2015/03/avoid-unplannedadmissions-03-15.pdf (accessed 7 March 2018).

[9] Garin, N., Koyanagi, A., Chatterji, S., Tyrovolas, S., Olava, B., Leonardi, M., Lara, E., Koskinen, S., TobiaszAdamczyk, B., Ayuso-Mateos, J.L. \& Haro, J.M. (2016). Global Multimorbidity Patterns: A Cross-Sectional, Population-Based, Multi-Country Study. Journals of Gerontology. Series A, Biological Sciences and Medical Sciences 71 (2) 205-214.

[10] Burt, J., Rick, J., Blakeman, T., Protheroe, J., Roland, M. \& Bower, P. (2014). Care plans and care planning in long term conditions: a conceptual model. Primary Health Care Research \& Development 15 (4) 342-354.

[11] Ipsos MORI. (2016). GP Patient Survey. Available at: https://gp-patient.co.uk (accessed 7 March 2018).

[12] Reeves, D., Hann, M., Rick, J., Rowe, K., Small, N., Burt, J., Roland, M., Protheroe, J., Blakeman, T., Richardson, G., Kennedy, A. \& Bower, P. (2014). Care plans and care planning in the management of long-term conditions in the UK: a controlled prospective cohort study. British Journal of General Practice 64 (626) e568e575.

[13] Burt, J., Roland, M., Paddison, C., Reeves, D., Campbell, J., Abel, G. \& Bower, P. (2012). Prevalence and benefits of care plans and care planning for people with long-term conditions in England. Journal of Health Services Research \& Policy 17 (Supplement 1) 64-71.

[14] Ipsos MORI. (2016). GP Patient Survey - Technical Annex 2015-2016 annual report. Available at: https://gppatient.co.uk/downloads/archive/2016/July/July\%202016 \%20National\%20Technical\%20Report.pdf (accessed 7 March 2018).

[15] StataCorp. (2013). Stata Statistical Software: Release 13. College Station, TX: StataCorp LP.

[16] Bouillion, K., Kivimaki, M., Hamer, M., Sabia, S., Fransson, E.I., Singh-Manoux, A., Gale, C.R. \& Batty,
G.D. (2013). Measures of frailty in population-based studies: an overview. BMC Geriatrics 13, 64.

[17] Vermunt, N.P.C.A., Harmsen, M., Westert, G.P., Olde Rikkert, M.G.M. \& Faber, M.J. (2017). Collaborative goal setting with elderly patients with chronic disease or multimorbidity: a systematic review BMC Geriatrics 17, 167.

[18] Blakemore, A., Hann, M., Howells, K., Panagioti, M., Sidaway, M., Reeves, D. \& Bower, P. (2016). Patient activation in older people with long-term conditions and multimorbidity: correlates and change in a cohort study in the United Kingdom. BMC Health Services Research 16 (1), 582.

[19] Patient activation measure. Available at: https://www.insigniahealth.com/research/archive/ (accessed 7 March 2018).

[20] Parsons, S., Winterbottom, A., Cross, P., et al. (2010). The quality of patient involvement and involvement in primary care. London: The King's Fund. Available at: http://www.picker.org/wp-content/uploads/2014/10/Thequality-of-patient-engagement...-primary-care.pdf (accessed 7 March 2018).

[21] Newbould, J., Burt, J., Bower, P., Blakeman, T., Kennedy, A., Rogers, A. \& Roland, M. (2012) Experiences of care planning in England; interviews with patients with long-term conditions. BMC Family Practice 13, 71. 